\title{
Matrix Metalloproteinase Production by COOH-Terminal Heparin-Binding Fibronectin Fragment in Rheumatoid Synovial Cells
}

\author{
Tadashi Yasuda, Makoto Shimizu, Takefumi Nakagawa, Sohel M. Julovi, and \\ Takashi Nakamura \\ Department of Orthopaedic Surgery, Kyoto University Graduate School of Medicine, Shogoin, Sakyo-ku, Japan
}

\begin{abstract}
SUMMARY: Fibronectin with IIICS region is present in rheumatoid synovium, and fibronectin fragments are increased in rheumatoid joints. We investigated the ability of $\mathrm{COOH}$-terminal heparin-binding fibronectin fragment $(\mathrm{COOH}-\mathrm{HBFN}-\mathrm{f})$ containing IIICS to induce matrix metalloproteinase (MMP) production and the role of mitogen-activated protein kinase (MAPK) pathway and CS-1 sequence that can bind $\alpha 4 \beta 1$ integrin in MMP induction by COOH-HBFN-f in rheumatoid synovial fibroblasts (RSF). When $\mathrm{RSF}$ in monolayer culture were incubated with $\mathrm{COOH}-\mathrm{HBFN}-\mathrm{f}, \mathrm{COOH}-\mathrm{HBFN}-\mathrm{f}$ stimulated the production of MMP-1, MMP-3, and MMP-13 by RSF in association with activation of extracellular signal-regulated kinase, p38 MAPK, and c-Jun $\mathrm{NH}_{2}$-terminal kinase. Immunoprecipitation of cell lysates demonstrated the presence of $\alpha 4$ integrin in cultured RSF. Similar to COOH-HBFN-f, treatment with CS-1 synthetic peptide derived from IIICS resulted in increased MMP production and activation of the kinases, although the MMP levels were low. Preincubation of RSF with anti- $\alpha 4$ integrin antibody resulted in partial suppression of the $\mathrm{COOH}-\mathrm{HBFN}$-f-stimulated MMP production. Inhibition studies using protein kinase inhibitors (PD98059 and SB203580) showed that those MAPK pathways contributed to MMP up-regulation by $\mathrm{COOH}-\mathrm{HBFN}-\mathrm{f}$ and CS-1. Thus, the present results have clearly shown that $\mathrm{COOH}-\mathrm{HBFN}-\mathrm{f}$ and CS-1 stimulate MMP production in association with activation of MAPK pathways in RSF. Integrin $\alpha 4 \beta 1$ may be partially involved in the MMP induction by COOH-HBFN-f. (Lab Invest 2003, 83:153-162).
\end{abstract}

F ibronectin (FN) is a family of glycoproteins present in body fluids and extracellular matrices. FN has various biologic functions, including cell attachment, cell migration, wound healing, and oncogenic transformation (Hynes, 1990). FN consists predominantly of three types of homologous repeating segments (designated I, II, and III). FN contains $\mathrm{NH}_{2}-$ terminal heparin-, gelatin-, cell-, and $\mathrm{COOH}$-terminal heparin-binding domains. Multiple isoforms of FN are produced from a single gene by alternative splicing at three distinct sites, EDA, EDB, and IIICS (Hynes, 1985). FN is ubiquitous within active rheumatoid synovium. Enhanced accumulation of FN is found on the inflamed synovial and pannus surfaces in the knee joints of patients with rheumatoid arthritis (RA) (Scott et al, 1981; Shiozawa and Ziff, 1983).

Rheumatoid synovial fibroblasts (RSF), found at the site of invasion of rheumatoid synovium into the adjacent cartilage and bone, play important roles in joint destruction at the cartilage-pannus contact. RSF extend out over the articular surface of cartilage, includ-

DOI: 10.1097/01.LAB.0000056999.08437.B2

Received October 3, 2002.

This work was supported by Grants-in-Aid for Scientific Research (No. 14571375) from the Japan Society for the Promotion of Science Address reprint requests to: $D r$. Tadashi Yasuda, Department of Orthopaedic Surgery, Kyoto University Graduate School of Medicine, 54 Kawahara-cho, Shogoin, Sakyo-ku, Kyoto 606-8507, Japan. E-mail: tadyasu@kuhp.kyoto-u.ac.jp ing the point of cartilage-pannus junction, where they express elevated collagenase levels (Wooley et al, 1977). Matrix metalloproteinases (MMPs) are thought to be critical players in rheumatoid joint destruction (Firestein et al, 1991). MMP-1 (collagenase 1) and MMP-13 (collagenase 3), found at elevated levels in RA (Vincenti, 2001), act at a committed step in the progression of RA, degrading type II collagen in cartilage (Firestein et al, 2001; Nagase and Woessner, 1999). MMP-3 (stromelysin 1) has activity against other components of cartilage matrix, such as proteoglycan and $\mathrm{FN}$, and can activate proMMP-1 and proMMP-13 (Nagase, 1997). Activator protein-1 (AP1 ), which includes members of the Jun and Fos families, is a pivotal transcriptional factor that regulates the production of cytokines and MMPs. The upstream regulatory regions of MMP genes including MMP-1 (Rutter et al, 1997) and MMP-13 (Pendas et al, 1997) contain the AP-1 recognition site. AP-1 can be activated by protein kinases that phosphorylate specific amino acid residues, especially by mitogenactivated protein kinase (MAPK) families (Karin et al, 1997). Three major MAPK families have been identified: extracellular signal-regulated kinase (ERK), p38 MAPK, and c-Jun $\mathrm{NH}_{2}$-terminal kinase (JNK) (Garrington and Johnston, 1999; Segar and Krebs, 1995). All of the three MAPK pathways are involved in the transcriptional regulation of Fos and Jun family genes. AP-1 components Jun and Fos have been identified in RA synovial tissues (Han et al, 1998). 
Integrins are heterodimeric transmembrane proteins that consist of $\alpha$ and $\beta$ subunits. Integrins bind extracellular matrix molecules and mediate cell adhesion, migration, and invasion during development, tissue repair, tumor invasion, and metastasis. In concert with growth factor or cytokine receptors, integrins regulate cell proliferation, differentiation, and survival (Giancotti and Mainiero, 1994; Hynes, 1992). Integrins also serve as cell surface receptors that transduce intracellular signals (Clark and Brugge, 1995; Defilippi et al, 1997; Giancotti and Ruoslahti, 1999; Schwarz et al, 1995). Although the cytoplasmic domains of the integrin $\alpha$ and $\beta$ subunits have no intrinsic enzymatic activity, integrin signaling is achieved by coupling signaling molecules to the cytoplasmic and transmembrane domains of the integrin subunits (Yamada and Miyamoto, 1995). Integrins activate signaling pathways that are either common to all integrins or heterodimerspecific (Giancotti, 1997). The cytoplasmic domains of $\alpha$ subunits may trigger signaling events that are specific for each individual integrin heterodimers (Sastry et al, 1996; Zhang et al, 1995). In addition, coupling of integrin receptors to MAPK pathways has been reported (Chen et al, 1994). RSF at the cartilage-pannus junction express integrin subunits $\alpha 4, \alpha 5$, and $\beta 1$ (Ishikawa et al, 1994). Integrin $\alpha 4 \beta 1$ recognizes CS-1 in alternatively spliced IIICS domain of fibronectin (Guan and Hynes, 1990; Wayner et al, 1989), whereas the arginine-glycine-aspartate (RGD) sequence within the central cell-binding domain of fibronectin is recognized by integrins $\alpha 5 \beta 1$ and $\alpha \mathrm{v} \beta 1$ (Damsky and Werb, 1992; Yamada, 1991).

Proteolytic fragments of $\mathrm{FN}$ are increased in RA synovial fluid (Carsons et al, 1985). Degradation products of FN are of interest as amplifiers or catalysts in diseased joints including RA and osteoarthritis (OA) (Homandberg, 1999) because of the ability to stimulate MMP induction (Homandberg et al, 1992; Werb et al, 1989; Yasuda and Poole, 2002). Although rabbit synovial fibroblasts plated on the central RGDcontaining fragments of $\mathrm{FN}$ have been shown to induce expression of MMP-1 and MMP-3 (Werb et al, 1989), MMP induction by fibronectin fragment (FN-f) in RSF remains to be clarified. Previous studies have shown that FN isoform with IIICS is present in RSF in synovial lining layer (Müller-Ladner et al, 1997). Recently, we have demonstrated that exogenous addition of $40 \mathrm{kd} \mathrm{COOH}$-terminal heparin-binding FN fragment (COOH-HBFN-f), which contains type III12 to 14 segments and IIICS, induces MMP-3 and MMP-13 in bovine articular cartilage culture (Yasuda and Poole, 2002). However, it is still unclear whether CS-1 sequence in IIICS of $\mathrm{COOH}-\mathrm{HBFN}-\mathrm{f}$, the recognition site for $\alpha 4 \beta 1$ integrin, plays a role in MMP induction. Thus, we attempted to analyze the ability of $\mathrm{COOH}-\mathrm{HBFN}-\mathrm{f}$ to induce MMP production in RSF and the role of MAPK pathway in MMP production by $\mathrm{COOH}$ HBFN-f. We further investigated the involvement of $\alpha 4 \beta 1$ integrin ligation with CS- 1 on RSF in the MMP production. The present study showed herein that $\mathrm{COOH}-\mathrm{HBFN}-f$ and the $\alpha 4 \beta 1$ integrin-binding synthetic peptide stimulated the production of MMP-1,
MMP-3, and MMP-13 in association with MAPK activation in RSF.

\section{Results}

\section{MMP Production by COOH-HBFN-f in RSF}

Our initial study was attempted to test the ability of $\mathrm{COOH}-\mathrm{HBFN}-f$ to induce MMP production in RSF.

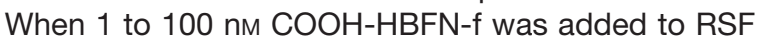
cultures, we found that $100 \mathrm{~nm} \mathrm{COOH}-\mathrm{HBFN}-\mathrm{f}$ caused the production of MMP-1, MMP-3, and MMP-13 by $\mathrm{RSF}$, in contrast to the barely detectable secretion of the enzymes in control or intact FN-treated cultures (Fig. 1A). Higher concentrations $(\sim 1 \mu \mathrm{M})$ of $\mathrm{COOH}-$ HBFN-f also produced a stimulatory effect on MMP induction in RSF (data not shown). Interleukin (IL)-1 $\beta$ induced MMPs verified the specificity of immunoreactive proteins induced by $\mathrm{COOH}-\mathrm{HBFN}-f$ (Fig. 1B). Compared with the levels induced by $2 \mathrm{ng} / \mathrm{ml} \mathrm{IL-1 \beta}$ (calculated protein band density as $100 \%$ ), the secreted levels of MMP-1, MMP-3, and MMP-13 in association with stimulation with $100 \mathrm{~nm} \mathrm{COOH}-$

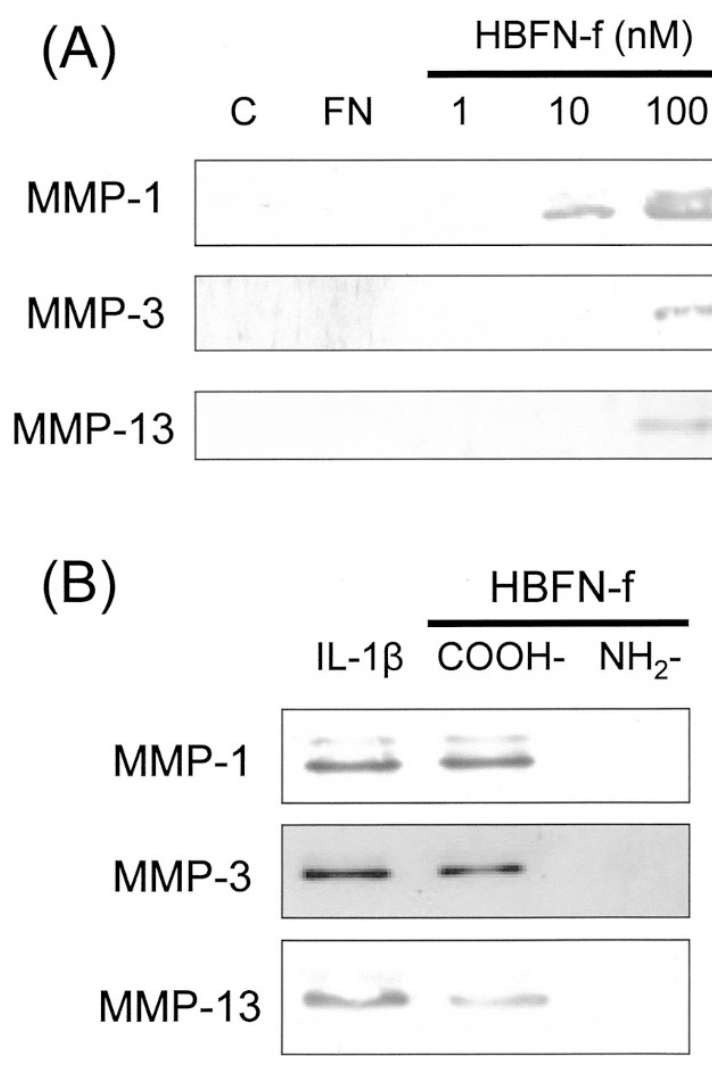

Figure 1.

Matrix metalloproteinase (MMP) induction by rheumatoid synovial fibroblasts (RSF) stimulated with $\mathrm{COOH}$-terminal heparin-binding fibronectin fragment (COOH-HBFN-f). A, RSF were incubated for 48 hours with 1 to $100 \mathrm{~nm}$ $\mathrm{COOH}-\mathrm{HBFN}-\mathrm{f}$ (indicated as HBFN-f) or human plasma fibronectin (FN) at 100 nм. Control cultures (indicated as $\mathrm{C}$ ) were without any additive. B, RSF were incubated for 48 hours with $100 \mathrm{~nm} \mathrm{COOH}$ - or $\mathrm{NH}_{2}$-terminal HBFN-f or $2 \mathrm{ng} / \mathrm{ml}$ interleukin (IL)-1 $\beta$. Conditioned media were analyzed by reducing $10 \%$ SDS-PAGE and immunoblotting using specific antibodies for MMP-1, MMP-3, and MMP-13. The amount of sample applied was determined on the basis of DNA content of RSF in the well. RSF derived from four patients with rheumatoid arthritis $(\mathrm{RA})$ were used for experiments with similar results. 
HBFN-f were $80 \pm 15,60 \pm 12$, and $40 \pm 5 \%$, respectively (mean $\pm \mathrm{SD}, n=4$ ). In contrast to $\mathrm{COOH}$ HBFN-f, $\mathrm{NH}_{2}$-terminal heparin-binding fibronectin fragment $\left(\mathrm{NH}_{2}-\mathrm{HBFN}-\mathrm{f}\right)$ without any known recognition site for integrins including $\alpha 4 \beta 1$, served as a negative control and failed to stimulate MMP production by RSF (Fig. 1B).

\section{MMP Production by COOH-HBFN-f Is Not via an IL-1-Mediated Pathway}

Whereas FN-f has been shown to stimulate the release of proinflammatory cytokines including IL-1 from cartilage (Homandberg et al, 1997), FN-f has been shown to increase MMP expression via an IL-1 autocrine loop in several studies. RGD integrin-binding sequence of FN enhances MMP-3 synthesis by chondrocytes in an IL-1-dependent manner (Arner and Tortorella, 1995). FN-f-induced MMP-3 production by human cartilage in culture can be partially blocked by neutralizing antibodies against IL-1 (Homandberg et al, 1997). Thus, the involvement of IL-1 in MMP production by $\mathrm{COOH}-\mathrm{HBFN}$-f-stimulated RSF was investigated using IL-1 receptor antagonist (IL-1ra) to competitively inhibit IL-1 interaction with its receptor. When RSF were incubated with IL-1ra at $100 \mathrm{ng} / \mathrm{ml}$ in the presence of $2 \mathrm{ng} / \mathrm{ml} \mathrm{IL-1 \beta}$, IL-1ra significantly blocked $\mathrm{IL}-1 \beta$-stimulated production of MMP-1, MMP-3, and MMP-13 (Fig. 2). In contrast, IL-1ra at $100 \mathrm{ng} / \mathrm{ml}$ failed to suppress the production of these MMPs by RSF stimulated with $100 \mathrm{~nm} \mathrm{COOH-HBFN-f} \mathrm{(Fig.} \mathrm{2),} \mathrm{indi-}$ cating that $\mathrm{COOH}-\mathrm{HBFN}-\mathrm{f}$ could induce the MMPs via an IL-1-independent pathway. Similar IL-1-independent effects of FN-f have been demonstrated in the previous studies on FN-f-induced nitric oxide synthesis in human chondrocytes (Gemba et al, 2002) and on FN-f-stimulated production of MMP-3 and MMP-13 in pig cartilage (Stanton et al, 2002).

\section{Activation of MAPK by COOH-HBFN-f in RSF}

We next examined whether treatment with $\mathrm{COOH}-$ HBFN-f results in activation of ERK, p38 MAPK, and

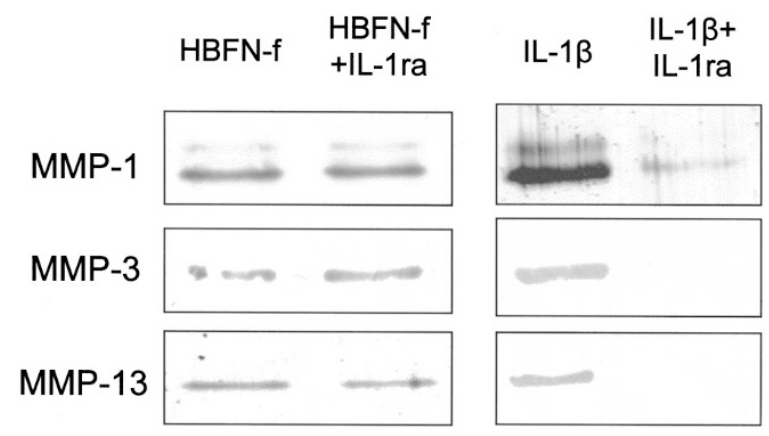

Figure 2.

Effects of IL-1 receptor antagonist (IL-1ra) on MMP production by $\mathrm{COOH}-$ HBFN-f-stimulated RSF. RSF were incubated for 48 hours with $100 \mathrm{~nm}$ COOH-HBFN-f (indicated as HBFN-f) or $2 \mathrm{ng} / \mathrm{ml} \mathrm{IL-1 \beta}$ in the presence or absence of IL-1ra at $100 \mathrm{ng} / \mathrm{ml}$. Conditioned media were analyzed by immunoblotting using specific antibodies for MMP-1, MMP-3, and MMP-13. The amount of sample applied was determined on the basis of DNA content of RSF in the well. Two separate experiments were performed with similar results.
JNK in RSF. After stimulation with $\mathrm{COOH}-\mathrm{HBFN}-\mathrm{f}$ at $100 \mathrm{nM}$, cell lysates were subjected to immunoblot analysis (Fig. 3). We used RSF stimulated with $2 \mathrm{ng} / \mathrm{ml}$ $\mathrm{IL}-1 \beta$ as a positive control because the proinflammatory cytokine has been shown to activate the three MAPK pathways in RSF (Schett et al, 2000). Enhanced phosphorylation of ERK $1 / 2$ by $\mathrm{COOH}-\mathrm{HBFN}-\mathrm{f}$ was observed from 10 to 30 minutes that peaked at 30 minutes, followed by the decline by 120 minutes. IL-1 $\beta$ also caused enhanced activation of ERK $1 / 2$ from 10 to 30 minutes with maximal activation at 30 minutes. $\mathrm{COOH}-\mathrm{HBFN}-\mathrm{f}$ caused significant activation of p38 MAPK at 120 minutes, whereas activation of p38 was observed from 10 minutes with the maximal activation at 120 minutes in IL- $1 \beta$-stimulated RSF. COOHHBFN-f also induced JNK activation in RSF. Treatment with $\mathrm{COOH}-\mathrm{HBFN}-\mathrm{f}$ resulted in phosphorylation of $54 \mathrm{kd} \mathrm{JNK} \mathrm{(p54)} \mathrm{at} 120$ minutes. Activation of p54 JNK by IL- $1 \beta$ was evident from 10 to 30 minutes and thereafter faded into control levels. The protein levels of ERK1/2, p38, and JNK (p54) were unchanged during the whole period of experiments.

\section{Intracellular Signaling Cascades Stimulated by COOH-HBFN-f Involved in MMP Induction in RSF}

To investigate which intracellular signaling cascades were involved in MMP induction by $\mathrm{COOH}-\mathrm{HBFN}-\mathrm{f}$ in RSF, we used the selective protein kinase inhibitors: PD98059, a specific MAPK, ERK-kinase (MEK) inhibitor that inhibits the ERK signaling cascade (Dudley et al, 1995), and SB203580, which selectively inhibits p38 MAPK at low concentrations $(\leq 1 \mu \mathrm{M})$ but which inhibits both p38 and JNK at high concentrations $(\geq 10$ $\mu \mathrm{M})$ (Whitmarsh et al, 1997) (Fig. 4). After preincubation with one of those inhibitors for 1 hour, RSF were
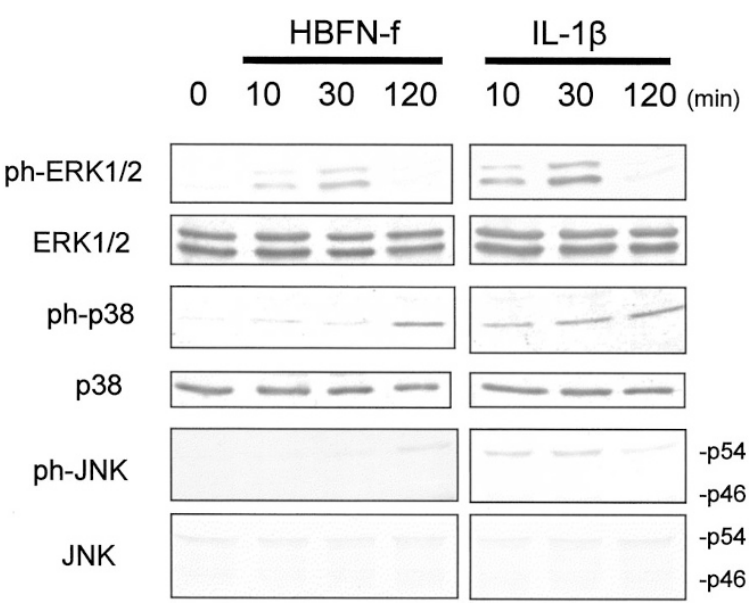

Figure 3.

Activation of extracellular signal-regulated kinase (ERK), p38 mitogenactivated protein kinase (MAPK), and c-Jun $\mathrm{NH}_{2}$-terminal kinase (JNK) in COOH-HBFN-f-stimulated RSF. After incubation with $100 \mathrm{~nm}$ COOH-HBFN- $f$ (indicated as HBFN-f) or $2 \mathrm{ng} / \mathrm{ml} \mathrm{IL-} 1 \beta$ for the time periods indicated, RSF were lysed as described. Cell lysates were subjected to SDS-PAGE, transferred to nitrocellulose, and immunoblotted with anti-pospho-ERK1/2 (ph-ERK1/2), anti-ERK1/2, anti-phospho-p38 MAPK (ph-p38), anti-p38, anti-phospho-JNK (ph-JNK), or anti-JNK antibody. RSF derived from four patients with RA were used for experiments with similar results. 


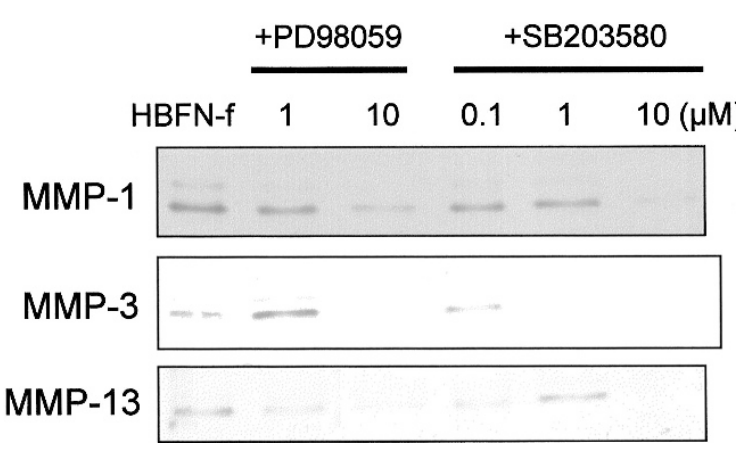

Figure 4.

Effects of MAPK inhibitors on MMP production by RSF stimulated with COOH-HBFN-f. After preincubation with PD98059 or SB203580 for 1 hour at the concentrations indicated, RSF were incubated for 48 hours with $100 \mathrm{~nm}$ $\mathrm{COOH}-\mathrm{HBFN}-f$ (indicated as HBFN-f). Conditioned media were analyzed by immunoblotting using specific antibodies for MMP-1, MMP-3, and MMP-13. The amount of sample applied was determined on the basis of DNA content of RSF in the well. RSF derived from four patients with RA were used for experiments with similar results.

stimulated for 24 hours with $\mathrm{COOH}-\mathrm{HBFN}-\mathrm{f}$ at $100 \mathrm{~nm}$. The MEK inhibitor at $10 \mu \mathrm{M}$ significantly blocked $\mathrm{COOH}-\mathrm{HBFN}$-f-stimulated production of MMP-1, MMP-3, and MMP-13. SB203580 at $1 \mu \mathrm{M}$ partially suppressed $\mathrm{COOH}-\mathrm{HBFN}-\mathrm{f}$-induced MMP-1 production; approximately $50 \%$ decrease in protein band intensity compared with $\mathrm{COOH}-\mathrm{HBFN}$-f-induced MMP-1 levels (the calculated protein band intensity as $100 \%)$. The inhibitor at $10 \mu \mathrm{m}$ completely inhibited the MMP-1 production. SB203580, even at $1 \mu \mathrm{M}$, completely blocked $\mathrm{COOH}-\mathrm{HBFN}$-f-induced production of MMP-3. However, SB203580 only at $10 \mu \mathrm{M}$ was capable of inhibiting $\mathrm{COOH}-\mathrm{HBFN}-\mathrm{f}-$ stimulated MMP-13 production in RSF.

\section{Identification of $\alpha 4$ Integrin in RSF}

Under the guidance of Jurkat cells as a positive control, immunoblot analysis with immunoprecipitated samples of RSF cell lysates with anti-integrin $\alpha 4$ antibodies, sc-6589 (Fig. 5A), and sc-6590 (data not shown) that recognize $\mathrm{COOH}$ - and $\mathrm{NH}_{2}$-terminal regions of $\alpha 4$ integrin, respectively, demonstrated the presence of $\alpha 4$ integrin subunit in RSF. Integrin $\alpha 4$ subunit was also found in RSF derived from three other patients with RA (Fig. 5B). These observations are consistent with the previous finding that cultured RSF express $\alpha 4$ integrin subunit (Müller-Ladner et al, 1997).

\section{MMP Production and MAPK Activation by CS-1 in RSF}

Because RSF expressed $\alpha 4$ integrin, we further investigated MMP induction with $\alpha 4 \beta 1$ integrin ligation with CS-1 peptide derived from IIICS in COOH-HBFN-f. Treatment with $10 \mu \mathrm{M}$ CS- 1 for 48 hours resulted in an increase in secreted levels of MMP-1, MMP-3, and MMP-13 in conditioned media detected by immunoblot analysis (Fig. 6A). Similar to CS-1, in line with the previous reports using RGD-containing peptide derived from III10 of central cell-binding domain in FN
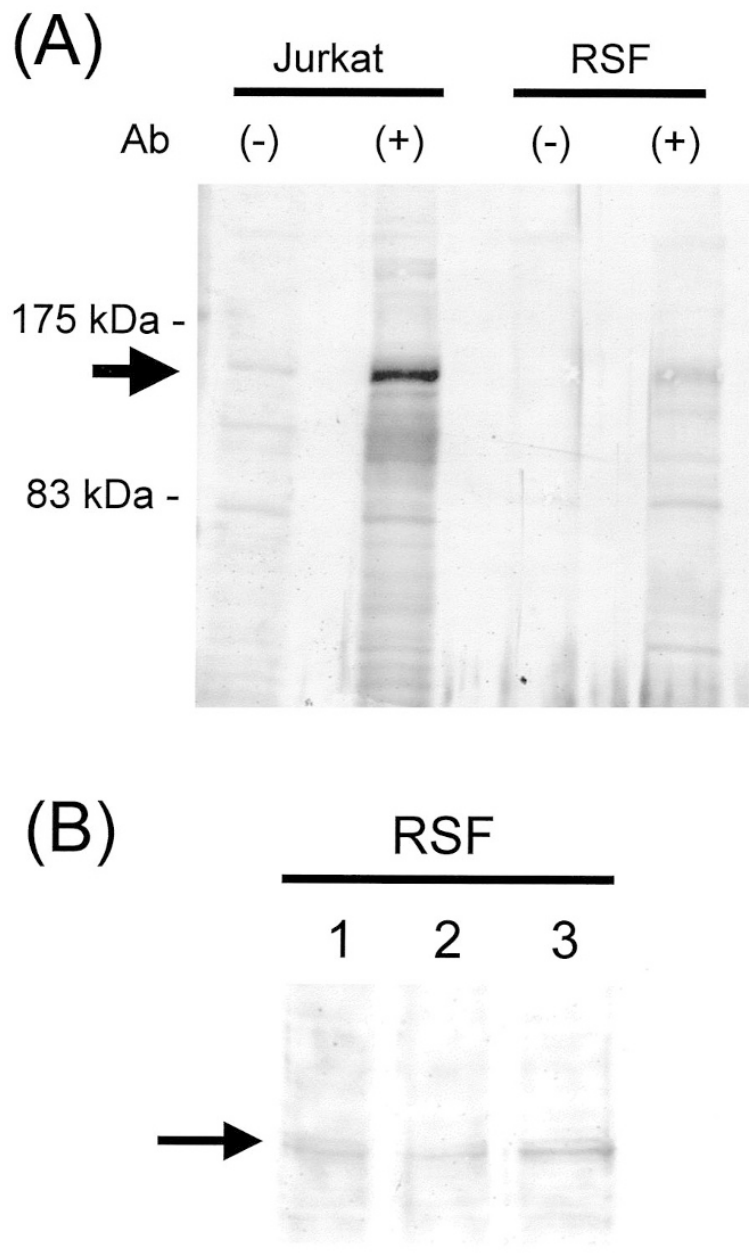

Figure 5

Immunoblotting for $\alpha 4$ integrin in RSF. A, Total cell lysates from RSF were subjected to immunoprecipitation with or without anti- $\alpha 4$ integrin antibody (sc-6589). The resulting protein complexes were resolved by reducing $6 \%$ SDS-PAGE, transferred to nitrocellulose, and immunoblotted with the antiintegrin $\alpha 4$ antibody. Jurkat cells were used as a positive control. Molecular weight markers $\left(\times 10^{3}\right)$ are indicated at left. B, Immunoblotting after immunoprecipitation with total cell lysates of RSF derived from three other patients (lanes 1-3). Arrows indicate the position of $\alpha 4$ integrin.

that can bind $\alpha 5 \beta 1$ and $\alpha \mathrm{v} \beta 1$ integrins (Werb et al, 1989), $10 \mu \mathrm{M}$ glycine-arginine-glycine-aspartateserine (GRGDS) as a positive control stimulated the MMP production by RSF (Fig. 6A). However, the levels of MMPs induced by CS-1 were low, compared with the levels by $\mathrm{COOH}-\mathrm{HBFN}-f$ (Fig. 6B). The protein band intensities of MMP-1, MMP-3, and MMP-13 with CS-1 stimulation were $35 \pm 14,29 \pm 10$, and $25 \pm$ $15 \%$ (mean $\pm \mathrm{SD}, n=4$ ), respectively, when those by $\mathrm{COOH}-\mathrm{HBFN}$-f were calculated as $100 \%$. In contrast to $\mathrm{CS}-1,10 \mu \mathrm{M}$ peptide $\mathrm{V}$ derived from the $\mathrm{III} 14$ repeat of $\mathrm{COOH}-\mathrm{HBFN}-\mathrm{f}$ as a negative control failed to induce those MMPs in RSF (Fig. 6B).

We also investigated MAPK activation in association with $\alpha 4 \beta 1$ integrin ligation with CS-1 at $10 \mu \mathrm{M}$ (Fig. 7). Stimulation of $\alpha 4 \beta 1$ integrin with CS-1 resulted in enhanced activation of ERK1/2 from 10 to 60 minutes that peaked at 30 minutes. CS-1 induced significant phosphorylation of p38 from 60 to 120 minutes in RSF. 


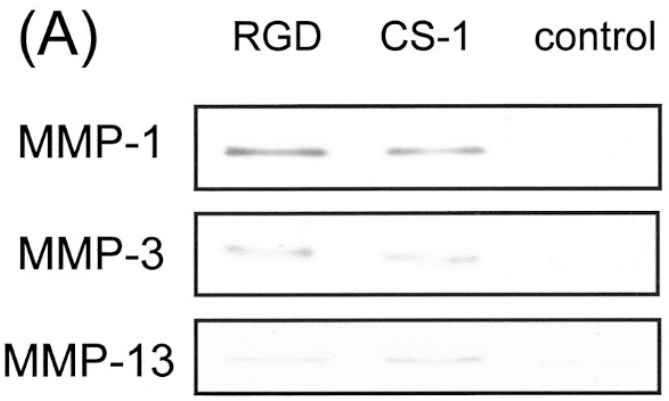

\section{(B) HBFN-f CS-1 peptide V}

MMP-1

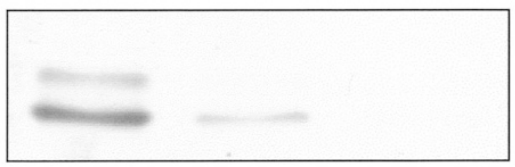

MMP-3

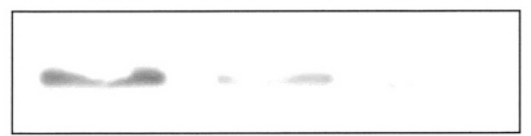

\section{MMP-13}

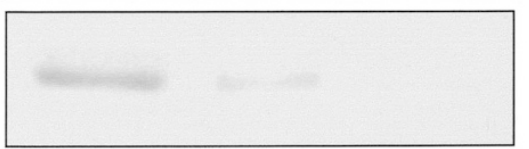

Figure 6.

MMP production by RSF with treatment with synthetic peptides. A, RSF were incubated for 48 hours with $10 \mu \mathrm{M}$ CS-1 peptide for $\alpha 4 \beta 1$ integrin or $10 \mu \mathrm{M}$ glycine-arginine-glycine-aspartate-serine (GRGDS) (indicated as RGD) for $\alpha 5 \beta 1$ and $\alpha \vee \beta 1$ integrins. Control cultures were without addition of synthetic peptides. B, RSF were incubated for 48 hours with $100 \mathrm{~nm} \mathrm{COOH-HBFN-f}$ (indicated as HBFN-f), $10 \mu \mathrm{M}$ CS-1, or $10 \mu \mathrm{m}$ peptide V. Conditioned media were analyzed by reducing 10\% SDS-PAGE and immunoblotting using specific antibodies for MMP-1, MMP-3, and MMP-13. The amount of sample applied was determined on the basis of DNA content of RSF in the well. RSF derived from four patients with RA were used for experiments with similar results.

Stimulation of $\alpha 4 \beta 1$ integrin with CS- 1 caused slight activation of p54 JNK from 60 to 120 minutes in RSF. Total protein levels of ERK1/2, p38, and p54 JNK were unchanged during the period of experiments. Pretreatment with PD98059 at $10 \mu \mathrm{M}$ resulted in complete inhibition of CS-1-stimulated production of MMP-1, MMP-3, and MMP-13 in RSF (Fig. 8). SB203580 at 10 $\mu \mathrm{M}$ completely blocked collagenase (MMP-1 and MMP-13) production by CS-1-stimulated RSF, whereas $1 \mu \mathrm{M}$ of the inhibitor failed to inhibit it (Fig. 8). SB203580 even at $1 \mu \mathrm{M}$ suppressed MMP-3 production by CS-1-stimulated RSF (Fig. 8).

\section{Inhibition of COOH-HBFN-f-Stimulated MMP Induction by Anti-a4 Integrin Antibody}

To determine the role of $\alpha 4$ integrin in $\mathrm{COOH}-\mathrm{HBFN}$ f-stimulated MMP production, we co-incubated RSF

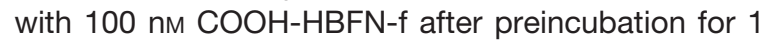
hour with $10 \mu \mathrm{g} / \mathrm{ml}$ anti- $\alpha 4$ integrin antibody (sc-6590), which recognizes an extracellular $\mathrm{NH}_{2}$-terminal region of $\alpha 4$ integrin of human origin. Compared with the

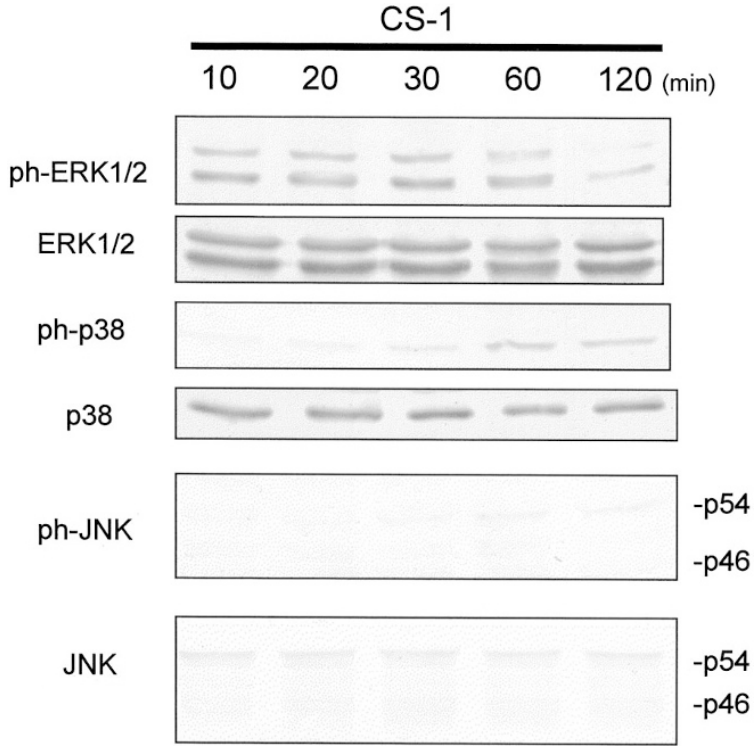

Figure 7.

Activation of ERK, p38, and JNK in RSF with $\alpha 4 \beta 1$ integrin ligation with CS-1. After incubation with CS-1 at $10 \mu \mathrm{m}$ for the time periods indicated, RSF were lysed as described. Cell lysates were subjected to SDS-PAGE, transferred to nitrocellulose, and immunoblotted with anti-ph-ERK1/2, anti-ERK1/2, anti-php38, anti-p38, anti-ph-JNK, or anti-JNK antibody. RSF derived from four patients with RA were used for experiments with similar results.

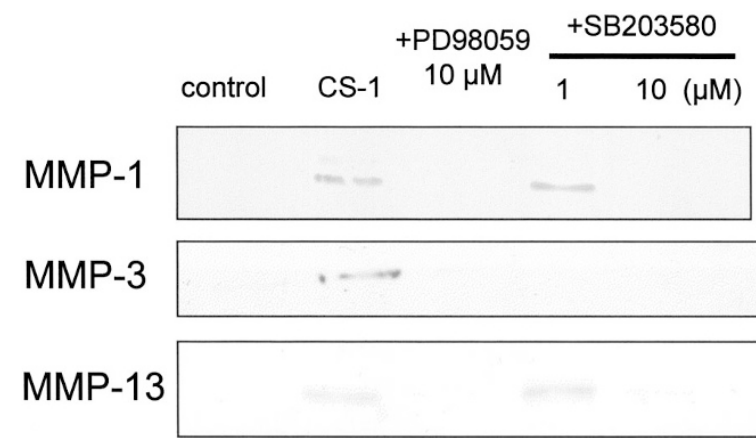

Figure 8.

Effects of MAPK inhibitors on MMP induction by $\alpha 4 \beta 1$ integrin stimulation with CS-1. RSF were pretreated for 1 hour with the indicated concentrations of PD98059 or SB203580 and thereafter stimulated for 48 hours with $10 \mu \mathrm{m}$ CS-1. Conditioned media were analyzed by SDS-PAGE and immunoblotting using specific antibodies for MMP-1, MMP-3, and MMP-13. The amount of sample applied was determined on the basis of DNA content of RSF in the well. RSF derived from four patients with RA were used for experiments with similar results.

protein band intensities of MMPs induced by $\mathrm{COOH}$ HBFN-f calculated as $100 \%$, the antibody blocked the enhanced production of MMP-1, MMP-3, and MMP- 13 by approximately 40,60 , and $50 \%$, respectively (Fig. 9). In contrast, nonspecific goat immunoglobulin $\mathrm{G}(\mathrm{lgG})$ at $10 \mu \mathrm{g} / \mathrm{ml}$ had no significant effect on the $\mathrm{COOH}-\mathrm{HBFN}$-f-stimulated MMP induction.

\section{Discussion}

In synovial joints with RA, invasion of synovial tissue into the adjacent cartilage matrix is observed in the form of a pannus, with proteolytic degradation of 


\section{HBFN-f+ anti-a4 Ab + +lgG HBFN-f}

MMP-1

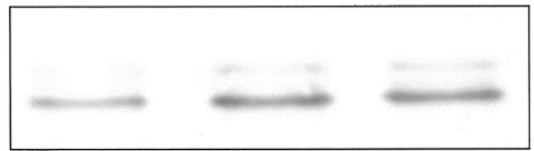

MMP-3

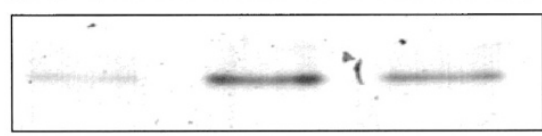

MMP-13

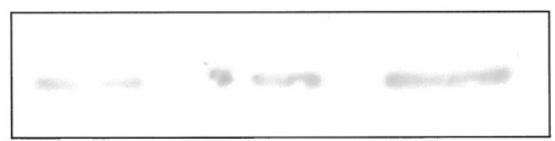

Figure 9.

Effects of anti- $\alpha 4$ integrin antibody on MMP production with COOH-HBFN- $f$ stimulation. RSF were pretreated for 1 hour with or without $10 \mu \mathrm{g} / \mathrm{ml}$ anti- $\alpha 4$ integrin antibody (sc-6590) or nonspecific immunoglobulin $G$ and thereafter stimulated for 48 hours with $100 \mathrm{~nm}$ COOH-HBFN-f (indicated as HBFN-f). Conditioned media were analyzed by SDS-PAGE and immunoblotting using specific antibodies for MMP-1, MMP-3, and MMP-13. The amount of sample applied was determined on the basis of DNA content of RSF in the well. Two separate experiments were performed with similar results.

articular cartilage and bone as a consequence (Shiozawa and Tokushima, 1992). Pannus invasion occurs at the junction between synovial tissue and cartilage. Pannus destroys cartilage by extension over the cartilage surface or direct penetration into the bare zone between cartilage and synovial insertion. The observation that cartilage degradation by pannus takes place in the absence of vascular supply (Shiozawa and Ziff, 1983) suggests that local factors at the cartilage-pannus junction are involved in the degradation processes. IL-1, found in the elevated levels in RA synovium (Wang et al, 1997) and synovial fluid (Kahle et al, 1992), is considered to be one of those factors. Up-regulation and overexpression of MMPs are commonly found in rheumatoid joint destruction (Firestein et al, 1991), and increased levels of collagenase are found in RSF at the cartilage-pannus junction (Wooley et al, 1977). Of these enzymes, particular attention has focused on MMP-1 (collagenase 1) and MMP-13 (collagenase 3) because they are induced in response to IL-1 and tumor necrosis factor (Vincenti, 2001). Indeed, collagenase activity has been shown to be required for cartilage invasion by IL-1 $\beta$ stimulated RSF (Wang et al, 1997). In the present study, we have demonstrated for the first time that COOH-HBFN-f containing both III12 to 14 and IIICS domains stimulates the production of collagenases (MMP-1 and MMP-13) and stromelysin 1 (MMP-3) by RSF in contrast to intact $\mathrm{FN}$ or $\mathrm{NH}_{2}-\mathrm{HBFN}-\mathrm{f}$ (Fig. 1). Because $\mathrm{FN}-\mathrm{f}$ concentrations found in RA joints are more than $1 \mu \mathrm{M}$ (Xie et al, 1992), the concentration (100 nm) used in the current study is within a concentration range that may be found in $\mathrm{RA}$ joints. In articular cartilage explant culture, $\mathrm{COOH}-\mathrm{HBFN}-\mathrm{f}$ at 100 nм causes type II collagen cleavage by collagenase after proteoglycan degradation in association with MMP-3 and MMP-13 production (Yasuda and Poole, 2002). Furthermore, significant proteoglycan release from cultured cartilage is found at FN-f concentrations as low as $20 \mathrm{~nm}$ (Homandberg et al, 1992). As shown in the role in chondrocyte activation, specific FN-f, such as $\mathrm{COOH}-\mathrm{HBFN}-\mathrm{f}$, in RA synovial fluid may be another local factor for cartilage destruction by RSF at the cartilage-pannus junction through collagenase induction in addition to proinflammatory cytokines.

Specific sequences have been found in the promoters of MMP genes that mediate the increase in gene expression, including AP-1 site that binds the Fos and Jun families of transcription factors (Auble and Brinckerhoff, 1991). RA synovium contains AP-1 with elevated activities compared with OA synovium (Han et al, 1998). Activation of MAPK families ERK, p38, and JNK results in the production of phosphorylated active AP-1 transcription factor (Eder, 1997; Whitmarsh and Davis, 1996). The three mammalian MAPK pathways have been characterized in detail: ERK1/2 pathway (Raf/MEK1, 2/ERK1, 2), JNK/stress-activated protein kinase pathway (MEK kinase-1-4/MKK4, 7/JNK1-3), and p38 pathway (MAPK kinase kinase/MKK3, $6 /$ p38 $\alpha, \beta$ ) (Westermarck and Kahari, 1999). Although recent studies have shown that $\mathrm{NH}_{2}-\mathrm{HBFN}-\mathrm{f}$ can activate those MAPKs in OA chondrocytes (Gemba et al, 2002) and COOH-HBFN-f activates MAPK cascade in human natural killer cells (Mainiero et al, 1998), the ability of FN-f to stimulate MAPK pathways in RSF has not been investigated. The present study has clearly demonstrated that exogenous addition of $\mathrm{COOH}$ HBFN-f causes phosphorylation of ERK1/2, JNK, and p38 in RSF. Increased FN-f in RA synovial fluid could contribute to the enhanced activation of ERK, p38, and JNK found in synovial tissues from patients with RA (Schett et al, 2000). Upstream events in activation of MAPK cascades in association with $\mathrm{COOH}-\mathrm{HBFN}-\mathrm{f}$ stimulation remain to be clarified.

The role of individual MAPK pathways in individual MMP expressions seems to vary with cell types and stimulus. All of the pathways of ERK, p38, and JNK contribute to MMP-1 expression in rabbit synovial fibroblasts (Barchowsky et al, 2000). Although IL-1 activation of MMP-13 in rabbit chondrocytes is primarily p38-dependent because it is blocked with p38 inhibitor SB203580 (Mengshol et al, 2000), p38 pathway plays no significant role in MMP-13 expression by synovial fibroblasts in rat adjuvant arthritis (Han et al, 2001). IL-1 as well as tumor necrosis factor- $\alpha$ and IL-6 is a potent activator of all of the three MAPK pathways in RSF (Schett et al, 2000), as shown in the present study (Fig. 3). In IL-1-stimulated RSF, the recently developed specific JNK inhibitor significantly inhibits expression of MMP-1 and MMP-3 in association with AP-1 suppression. In the cells, ERK/MEK inhibitor (PD98059) weakly inhibits IL-1-induced MMP-1 expression with modest suppression of AP-1 binding. In contrast, p38 inhibitor (SB203580) has no significant effect on MMP-1 expression or AP-1 binding (Han et al, 2001). The present results suggest different roles of individual MAPK pathways in the production of individual MMPs by RSF in association with $\mathrm{COOH}$ HBFN-f stimulation. In RSF monolayer culture, ERK 
seems to be involved in MMP-1, MMP-3, and MMP-13 production with $\mathrm{COOH}-\mathrm{HBFN}-f$ stimulation because PD98059 effectively blocked the MMP production (Fig. 4). Because low concentration (1 $\mu \mathrm{M})$ of SB203580 inhibited MMP-3 production (Fig. 4), p38 MAPK may contribute to MMP-3 induction by $\mathrm{COOH}-$ HBFN-f. In contrast, because only high levels $(10 \mu \mathrm{M})$ of SB203580 were able to block collagenase induction (Fig. 4), JNK seems to promote the production of MMP-1 and MMP-13 by COOH-HBFN-f. However, high concentrations of the inhibitor may inhibit p38 and JNK as well as other kinases that could alter cellular function. The precise role of JNK in the collagenase induction with $\mathrm{COOH}-\mathrm{HBFN}-f$ stimulation remains to be determined, ideally by using a selective JNK inhibitor.

There is an increasing body of evidence that cellmatrix interactions regulate MMP induction through integrins (Ivaska and Heino, 2000). At the cartilagepannus junction, RSF are found to express integrin subunits $\alpha 4, \alpha 5$, and $\beta 1$ (Ishikawa et al, 1994). Normal synoviocytes are unable to adhere to the cartilage surface, whereas in RA, at the cartilage-pannus junction, RSF adhere directly to the cartilage surface (Ishikawa et al, 1991). FN in the superficial region of articular cartilage is likely to serve as a local factor for pannus extension on RA cartilage. RGD-containing synthetic peptide inhibits synovial tissue extension on articular cartilage, indicating an important role of $\alpha 5 \beta 1$ and $\alpha \mathrm{v} \beta 1$ integrins at the cartilage-pannus junction in pannus attachment to cartilage, probably through the binding of integrins to FN (Shiozawa et al, 1992). However, although FN isoform containing IIICS are found to be present in rheumatoid synovium (MüllerLadner et al, 1997), inhibition studies using synthetic peptides have shown that RSF is unlikely to adhere FN on cartilage via $\alpha 4 \beta 1$ integrin (Hino et al, 1996). Similar to $\mathrm{COOH}-\mathrm{HBFN}-\mathrm{f}$ (Figs. 1 and 3), the present study demonstrated that exogenous addition of CS-1 peptide derived from IIICS of $\mathrm{COOH}-\mathrm{HBFN}$-f stimulates MMP induction (Fig. 6) in association with MAPK activation (Fig. 7) in RSF. In addition, the MAPK inhibitors (PD98059 and SB203580) provided similar inhibitory effects on MMP production by RSF stimulated with CS-1 (Fig. 8) and COOH-HBFN-f (Fig. 4). From the observation that anti- $\alpha 4$ integrin antibody can partially block $\mathrm{COOH}-\mathrm{HBFN}-\mathrm{f}-$ stimulated MMP production (Fig. 9), it is likely that $\mathrm{COOH}-\mathrm{HBFN}-\mathrm{f}$ uses $\alpha 4 \beta 1$ integrin expressed on RSF as one of the signaling receptors for MMP induction. Compared with CS-1 peptide, $\mathrm{COOH}-\mathrm{HBFN}-f$ can induce greater levels of MMPs (Fig. 6B). Previous studies have shown similar findings that excessive amounts (1 mm) of RGD peptide are required to induce proteoglycan release in cartilage explant culture, whereas FN-f with RGD sequence at $1 \mu \mathrm{M}$ causes stronger release of proteoglycan (Homandberg et al, 1992). Thus, FN-f could activate integrins more effectively than synthetic peptides. Alternatively, MMP induction by $\mathrm{COOH}-\mathrm{HBFN}-$ f-stimulated RSF may involve other mechanisms. Because cell surface heparan sulfate and chondroitin sulfate are implicated in cell adhesion to several sites in the III12 to 14 domains of COOH-HBFN-f (Drake et al, 1992; lida et al, 1992), binding of COOH-HBFN-f with cell surface proteoglycans may contribute to MMP induction, which is under investigation.

\section{Materials and Methods}

\section{Materials}

Anti-human integrin $\alpha 4$ antibodies (C-20: sc-6589; N-19: sc-6590) were purchased from Santa Cruz Biotechnology, Inc. (Santa Cruz, California). Antihuman MMP-1 (M4177), MMP-3 (M4802), and MMP-13 (M4052) antibodies were obtained from Sigma. Anti-ERK (K-23; sc-94) and -p38 MAPK (C-20; sc-535) were purchased from Santa Cruz Biotechnology, Inc. Anti-phospho-ERK, -phospho-p38 kinase, -JNK, and -phospho-JNK were obtained from Cell Signaling Technology (Beverly, Massachusetts). Alkaline phosphatase-conjugated anti-rabbit IgG was purchased from Southern Biotechnology Associates, Inc. (Birmingham, Alabama). Alkaline phosphataseconjugated anti-goat IgG and nonspecific goat IgG were obtained from Zymed Laboratories, Inc. (South San Francisco, California). Synthetic peptides peptide V (WQPPRARI), CS-1 (DELPQLVTLPHPNLHGPEILDVPST), and GRGDS were purchased from Takara Shuzo Company (Kusatsu, Japan). Human plasma FN and $\mathrm{COOH}-\mathrm{HBFN}$-f prepared from human plasma FN with $\alpha$-chymotrypsin digestion were obtained from GIBCO BRL (Rockville, Maryland). The 40-kd COOHHBFN-f contains a heparin-binding region with type III12 to 14 segments and IIICS. $\mathrm{NH}_{2}-\mathrm{HBFN}-\mathrm{f}$, which is a proteolytic $30-k d$ fragment of human plasma $\mathrm{FN}$ with the first type I repeats, was purchased from Sigma. The purity of protein preparation has been confirmed as shown in our previous studies (Yasuda and Poole, 2002). PD98059 and SB203580 were from Wako Pure Chemical Industries (Osaka, Japan). Recombinant human IL-1 $\beta$ and IL-1ra were purchased from R\&D Systems (Minneapolis, Minnesota).

\section{Rheumatoid Synovial Cell Culture and Preparation of Cell Lysate}

Synovial tissues were obtained at knee joint replacement surgery from four patients who fulfilled the American College of Rheumatology (1987) revised criteria. Samples were immediately prepared for culture of RSF. The tissue was minced into small pieces, digested enzymatically, and filtered through a nylon mesh. The released cells were grown on $75 \mathrm{~cm}^{2}$ dishes (Corning, New York) in Dulbecco's modified Eagle's medium containing 100 units/ml penicillin, 100 units/ml streptomycin, and $10 \mathrm{~mm}$ HEPES (DMEM; all from GIBCO BRL) in the presence of $10 \%$ heatinactivated fetal bovine serum (ICN Biomedicals, Inc., Aurora, Ohio) in a humidified $5 \% \mathrm{CO}_{2}$ atmosphere at $37^{\circ} \mathrm{C}$. At confluence, cells were trypsinized, split at a $1: 3$ ratio, and cultured in DMEM with $10 \%$ fetal bovine serum. After 3 to 5 passages, RSF were plated on 35-mm six-well plates (Corning). At confluence, the cells were used for experiments. After extensive wash 
with PBS, all experiments were done under serum-free conditions. RSF were incubated with peptide V, CS-1, GRGDS, FN, HBFN-f, or IL-1 $\beta$. In some experiments, IL-1 ra was also added together with $\mathrm{COOH}-\mathrm{HBFN}-\mathrm{f}$ or IL-1 $\beta$. In other experiments, after pretreatment with one of the MAPK-specific inhibitors for 1 hour, RSF were stimulated with $\mathrm{COOH}-\mathrm{HBFN}-\mathrm{f}, \mathrm{CS}-1$, or IL-1 $\beta$. In another set of experiments, after preincubation with anti- $\alpha 4$ integrin antibody (sc-6590) or nonspecific IgG for 1 hour, RSF were co-incubated with $\mathrm{COOH}$ HBFN-f. Assays of endotoxin levels in $100 \mathrm{~nm} \mathrm{COOH}-$ and $\mathrm{NH}_{2}$-HBFN-f solutions before use showed minimal levels of detection of 6 to 8 and $\sim 20 \mathrm{ng} / \mathrm{ml}$, respectively.

After incubation for various periods of time at $37^{\circ} \mathrm{C}$, cell lysates were prepared after the harvest of conditioned media for assays. Briefly, cells were washed twice with cold PBS and then lysed in a lysis buffer containing $50 \mathrm{~mm}$ Tris ( $\mathrm{pH} 7.5), 150 \mathrm{~mm} \mathrm{NaCl}, 5 \mathrm{~mm}$ EDTA, $10 \mathrm{~mm} \mathrm{NaF}, 2$ mм Na $\mathrm{VO}_{4}$, $1 \mathrm{~mm}$ phenylmethylsulfonyl fluoride, $5 \mu \mathrm{g} / \mathrm{ml}$ aprotinin, $2 \mathrm{~mm}$ $\mathrm{N}$-ethylmaleimide, and $1 \%$ Triton $\mathrm{X}-100$ at $4{ }^{\circ} \mathrm{C}$. Total cell lysates were cleared by centrifugation at $16,000 \mathrm{~g}$ for 10 minutes at $4^{\circ} \mathrm{C}$.

\section{Immunoblot Analysis}

Total cell lysates and conditioned media were heated with SDS-PAGE sample buffer at $80^{\circ} \mathrm{C}$ for 20 minutes. Proteins were separated by SDS-PAGE under reducing conditions and thereafter transferred onto nitrocellulose membranes (Schleicher \& Schuell, Dassel, Germany). Membranes were blocked in Tris-buffered saline (50 mм Tris [pH 7.5], $150 \mathrm{~mm} \mathrm{NaCl)} \mathrm{containing}$ $5 \%$ nonfat dry milk and $0.1 \%$ Tween 20 and incubated with the first antibody (concentration 1/1000) overnight at $4^{\circ} \mathrm{C}$. After incubation with the alkaline phosphatase-conjugated second antibody (concentration 1/1000) for 3 hours at room temperature, immunoreactive bands were visualized using 5-bromo-4-chloro-3-indolyl phosphate and nitroblue tetrazolium. Protein band intensity was evaluated by densitometry using National Institutes of Health image.

\section{Immunoprecipitation}

At confluence after three to four passages, after being wash with cold PBS, RSF were lysed on $75-\mathrm{cm}^{2}$ dishes as described above. Total cell lysates were first incubated overnight at $4^{\circ} \mathrm{C}$ with or without the antibody recognizing $\alpha 4$ integrin subunit, followed by the addition of protein G-Sepharose, and then incubated for additional 3 hours at $4^{\circ} \mathrm{C}$. The precipitates were washed five times with the lysis buffer and thereafter boiled with SDS-PAGE sample buffer for 5 minutes to dissociate the proteins. The immunoprecipitated proteins were detected using the first antibody against integrin $\alpha 4$ (concentration 1/1000) and the alkaline phosphatase-conjugated second antibody (concentration 1/1000) by immunoblot analysis under reducing conditions, as described above.

\section{DNA Assay}

After collection of conditioned media, cultured RSF were digested with $0.5 \mathrm{mg} / \mathrm{ml}$ proteinase $\mathrm{K}$ in $50 \mathrm{~mm}$ Tris- $\mathrm{HCl}\left(\mathrm{pH} \mathrm{7.5)}\right.$ for 6 hours at $37^{\circ} \mathrm{C}$. DNA content in proteinase $\mathrm{K}$ digests was determined as described previously (Labarca and Paigen, 1980). We found no significant difference of DNA content in RSF between any treatment groups (data not shown).

\section{References}

Arnett FC, Edworthy SM, Bloch DA, McShane DJ, Fries JF, Cooper NS, Healey LA, Kaplan SR, Liang MH, Luthra HS, Medsger TA, Mitchell DM, Neustadt DH, Pinals RS, Schaller JG, Sharp JT, Wilder RL, and Hunder GG (1988). The American Rheumatism Association 1987 revised criteria for the classification of rheumatoid arthritis. Arthritis Rheum 31:315-324.

Arner EC and Tortorella MD (1995). Signal transduction through chondrocyte integrin receptors induces matrix metalloproteinase synthesis and synergizes with interleukin-1. Arthritis Rheum 38:1304-1314.

Auble DT and Brinckerhoff CE (1991). The AP-1 sequence is necessary but not sufficient for phorbol induction of collagenase in fibroblasts. Biochemistry 30:4629-4635.

Barchowsky A, Frleta D, and Vincenti MP (2000). Integration of the NF- $\kappa$ B and mitogen-activated protein kinase/AP-1 pathways at the collagenase-1 promoter: Divergence of IL-1 and TNF-dependent signal transduction in rabbit primary synovial fibroblasts. Cytokine 12:1469-1479.

Carsons S, Lavietes BB, Diamond HS, and Kinney SG (1985). The immunoreactivity, ligand and cell binding characteristics of rheumatoid synovial fluid fibronectin. Arthritis Rheum 28:601-612.

Chen Q, Kinch MS, Lin TH, Burridge K, and Juliano RL (1994). Integrin-mediated cell adhesion activates mitogen-activated protein kinases. J Biol Chem 269:26602-26605.

Clark EA and Brugge JS (1995). Integrins and signal transduction pathway: The road taken. Science 268:233-239.

Damsky CH and Werb Z (1992). Signal transduction by integrin receptors for extracellular matrix: Cooperative processing of extracellular information. Curr Opin Cell Biol 4:772-781.

Defilippi P, Gismondi A, Santoni A, and Tarone G (1997). Signal transduction by integrins. Defilippi $P$, Gismondi $A$, Santoni A, and Tarone G, editors. Austin: Springer Publishing Company, 1-182.

Drake SL, Klein DJ, Mickelson DJ, Oegema TR, Furcht LT, and McCarthy JB (1992). Cell surface phosphatidylinositolanchored heparan sulfate proteoglycan initiates mouse melanoma cell adhesion to a fibronectin-derived, heparinbinding synthetic peptide. J Cell Biol 117:1331-1341.

Dudley DT, Pang L, Decker SJ, Bridges AJ, and Saltiel AR (1995). A synthetic inhibitor of the mitogen-activated protein kinase cascade. Proc Natl Acad Sci USA 92:7686-7689.

Eder J (1997). Tumor necrosis factor alpha and interleukin-1 signaling: Do MAPKK kinases connect it all? Trends Pharmacol Sci 18:319-322.

Firestein GS (2001). Etiology and pathogenesis of rheumatoid arthritis. In: Ruddy S, Harris ED, Sledge CB, editors. Kelly's 
textbook of rheumatology. Philadelphia: W.B. Saunders, 921-966.

Firestein GS, Paine MM, and Littman BH (1991). Gene expression (collagenase, tissue inhibitor of metalloproteinases, complement and HLA-DR) in rheumatoid arthritis and osteoarthritis synovium. Quantitative analysis and effect of intraarticular corticosteroids. Arthritis Rheum 34:1094-1105.

Garrington TP and Johnston GL (1999). Organization and regulation of mitogen-activated protein kinase signaling pathways. Curr Opin Cell Biol 11:211-218.

Gemba T, Valbracht J, Alsalameh S, and Lotz M (2002). Focal adhesion kinase and mitogen-activated protein kinases are involved in chondrocyte activation by the $29-\mathrm{kDa}$ aminoterminal fibronectin fragment. J Biol Chem 277:907-911.

Giancotti FG (1997). Integrin signaling: Specificity and cell cycle progression. Curr Opin Cell Biol 9:691-700.

Giancotti FG and Mainiero F (1994). Integrin-mediated adhesion and signaling in tumorigenesis. Biochem Biophys Acta 1198:47-64.

Giancotti FG and Ruoslahti E (1999). Integrin signaling. Science 285:1028-1032.

Guan J-L and Hynes RO (1990). Lymphoid cells recognize an alternatively spliced segment of fibronectin via the integrin receptor $\alpha 4 \beta 1$. Cell 60:53-61.

Han Z, Boyle DL, Chang L, Bennett B, Karin M, Yang L, Manning AM, and Firestein GS (2001). C-Jun N-terminal kinase is required for metalloproteinase expression and joint destruction in inflammatory arthritis. J Clin Invest 108:73-81.

Han Z, Boyle DL, Manning AM, and Firestein GS (1998). AP-1 and $N F-\kappa B$ regulation in rheumatoid arthritis and murine collagen-induced arthritis. Autoimmunity 28:197-208.

Hino K, Maeda T, Sekiguchi K, Shiozawa K, Hirano H, Sakashita E, and Shiozawa H (1996). Adherence of synovial cells on EDA-containing fibronectin. Arthritis Rheum 39: 1685-1692.

Homandberg GA (1999). Potential regulation of cartilage metabolism in osteoarthritis by fibronectin fragments. Front Biosci 4:D713-D730.

Homandberg GA, Hui F, Wen C, Purple C, Bewsey K, Koepp H, Huch K, and Harris A (1997). Fibronectin-fragmentinduced cartilage chondrolysis is associated with release of catabolic cytokines. Biochem J 321:751-757.

Homandberg GA, Meyers R, and Xie DL (1992). Fibronectin fragments cause chondrolysis of bovine articular cartilage slices in culture. J Biol Chem 267:3597-3604.

Hynes RO (1985). Molecular biology of fibronectin. Annu Rev Cell Biol 1:67-90.

Hynes RO (1990). Fibronectins. New York: Springer-Verlag.

Hynes RO (1992). Integrins: Versatility, modulation, and signaling in cell adhesion. Cell 69:11-25.

lida J, Skubitz AP, Furcht LT, Wayner EW, and McCarthy JB (1992). Coordinate role for cell surface chondroitin sulfate proteoglycan and $\alpha_{4 \beta 1}$ in mediating melanoma cell adhesion to fibronectin. J Cell Biol 118:431-444.

Ishikawa H, Hirata S, Nishibayashi Y, Imura S, Kubo H, and Ohno O (1994). The role of adhesion molecules in synovial pannus formation in rheumatoid arthritis. Clin Orthop 300: 297-303.
Ishikawa H, Ohno O, Saura R, Matsubara T, Kuroda T, and Hirohata K (1991). Cytokine enhancement of monocyte/ synovial cell attachment to the surface of cartilage: A possible trigger of pannus formation in arthritis. Rheumatol Int 11:31-36.

Ivaska J and Heino J (2000). Adhesion receptors and cell invasion: Mechanisms of integrin-guided degradation of extracellular matrix. Cell Mol Life Sci 57:16-24.

Kahle P, Saal JG, Schaudt K, Zacher J, Fritz P, and Pawelec $G$ (1992). Determination of cytokines in synovial fluids: Correlation with diagnosis and histomorphological characteristics of synovial tissue. Ann Rheum Dis 51:731-734.

Karin M, Liu ZG, and Zandi E (1997). AP-1 function and regulation. Curr Opin Cell Biol 9:240-246.

Labarca C and Paigen K (1980). A simple, rapid and sensitive DNA assay procedure. Anal Biochem 102:344-352.

Mainiero F, Gismondi A, Soriani A, Cippitelli M, Palmieri G, Jacobelli J, Piccoli M, Frati L, and Santoni A (1998). Integrinmediated ras-extracellular regulated kinase (ERK) signaling regulates interferon gamma production in human natural killer cells. J Exp Med 188:1267-1275.

Mengshol JA, Vincenti MP, Coon Cl, Barchowsky A, and Brinckerhoff CE (2000). Interleukin-1 induction of collagenase-3 (matrix metalloproteinase 13) gene expression in chondrocytes requires p38, c-Jun N-terminal kinase, and nuclear factor $\kappa \mathrm{B}$ : Differential regulation of collagenase 1 and collagenase 3. Arthritis Rheum 43:801-811.

Müller-Ladner U, Elices MJ, Kriegsmann JB, Strahl D, Gay RE, Firestein GS, and Gay S (1997). Alternatively spliced CS-1 fibronectin isoform and its receptor VLA-4 in rheumatoid arthritis synovium. J Rheumatol 24:1873-1880.

Nagase H (1997). Activation mechanisms of matrix metalloproteinases. Biol Chem 378:151-160.

Nagase $\mathrm{H}$ and Woessner Jr JF (1999). Matrix metalloproteinases. J Biol Chem 274:21491-21494.

Pendas AM, Balbin M, Llano E, Jimenez MG, and Lopez-Otin C (1997). Structural analysis and promoter characterization of human collagenase-3 gene (MMP-13). Genomics 40:222233.

Rutter JL, Benbow U, Coon Cl, and Brinckerhoff CE (1997). Cell-type specific regulation of human interstitial collagense-1 gene expression by interleukin-1 $\beta$ (IL-1 $\beta)$ in human fibroblasts and BC-8701 breast cancer cells. J Cell Biochem 66:322-336.

Sastry SK, Lakonishok M, Thomas DA, Muschler J, and Horwitz AF (1996). Integrin $\alpha$ subunit ratios, cytoplasmic domains, and growth factor synergy regulate muscle proliferation and differentiation. J Cell Biol 133:169-184.

Schett G, Tohidast-Akrad M, Smolen JS, Schmid BJ, Steiner C-W, Bitzan P, Zenz P, Redlich K, Xu Q, and Steiner G (2000). Activation, differential localization, and regulation of the stress-activated protein kinases, extracellular signalregulated kinase, c-Jun $\mathrm{N}$-terminal kinase, and p38 mitogenactivated protein kinase, in synovial tissue and cells in rheumatoid arthritis. Arthritis Rheum 43:2501-2512.

Schwarz MA, Scaller MD, and Ginsberg MH (1995). Integrins: Emerging paradigms of signal transduction. Annu Rev Cell Dev Biol 11:549-599. 
Scott DL, Delamare JP, and Walton KW (1981). The distribution of fibronectin in the pannus in rheumatoid arthritis. $\mathrm{Br} \mathrm{J}$ Exp Pathol 62:362-368.

Segar R and Krebs EG (1995). The MAPK signaling cascade. FASEB J 9:726-735.

Shiozawa S and Tokushima T (1992). Contribution of synovial mesenchymal cells to the pathogenesis of rheumatoid arthritis. Semin Arthritis Rheum 21:267-273.

Shiozawa S, Yoshihara R, Kuroki Y, Fujita T, Shiozawa K, and Imura S (1992). Pathogenic importance of fibronectin in the superficial region of articular cartilage as a local factor for the induction of pannus extension on rheumatoid articular cartilage. Ann Rheum Dis 51:869-873.

Shiozawa S and Ziff M (1983). Immunoelectron microscopic demonstration of fibronectin in rheumatoid pannus and at the cartilage-pannus junction. Ann Rheum Dis 42:254-263.

Stanton H, Ung L, and Fosang AJ (2002). The $45 \mathrm{kDa}$ collagen-binding fragment of fibronectin induces matrix metalloproteinase- 13 synthesis by chondrocytes and aggrecan degradation by aggrecanases. Biochem J 364:181-190.

Vincenti MP (2001). The matrix metalloproteinase (MMP) and tissue inhibitor of metalloproteinase (TIMP) genes. Transcriptional and posttranscriptional regulation, signal transduction and cell-type-specific expression. Methods Mol Biol 151: 121-148.

Wang AZ, Wang JC, Fisher GW, and Diamond HS (1997). Interleukin- $\beta$-stimulated invasion of articular cartilage by rheumatoid synovial fibroblasts is inhibited by antibodies to specific integrin receptors and by collagenase inhibitors. Arthritis Rheum 40:1298-1307.

Wayner EA, Garcia-Pardo A, Humphries MJ, McDonald A, and Carter WG (1989). Identification and characterization of the $T$ lymphocyte adhesion receptor for an alternative cell attachment domain (CS-1) in plasma fibronectin. J Cell Biol 109:1321-1330.
Werb Z, Tremble PM, Behrendtsen O, Crowley E, and Damsky CH (1989). Signal transduction through the fibronectin receptor induces collagenase and stromelysin gene expression. J Cell Biol 109:877-889.

Westermarck J and Kahari VM (1999). Regulation of matrix metalloproteinase expression in tumor invasion. FASEB $\mathrm{J}$ 13:781-792.

Whitmarsh AJ and Davis RJ (1996). Transcription factor AP-1 regulation by mitogen-activated protein kinase signal transduction pathways. J Mol Med 74:589-607.

Whitmarsh AJ, Yang SH, Su MS, Sharrocks AD, and Davis RJ (1997). Role of p38 and JNK mitogen-activated protein kinases in the activation of ternary complex factors. Mol Cell Biol 17:2360-2371.

Wooley DE, Crossley MJ, and Evanson JM (1977). Collagenase at the sites of cartilage erosion in the rheumatoid joint. Arthritis Rheum 20:1231-1239.

Xie D-L, Meyers R, and Homandberg GA (1992). Fibronectin fragments in osteoarthritic synovial fluid. J Rheumatol 19: 1448-1452.

Yamada KM (1991). Adhesive recognition sequences. J Biol Chem 266:12809-12812.

Yamada KM and Miyamoto S (1995). Integrin transmembrane signaling and cytoskeletal control. Curr Opin Cell Biol 7:681689.

Yasuda T and Poole AR (2002). A fibronectin fragment induces type II collagen degradation by collagenase through an interleukin-1-mediated pathway. Arthritis Rheum 46:138148.

Zhang Z, Vuori K, Reed JC, and Ruoslahti E (1995). The $\alpha 5 \beta 1$ integrin supports survival of cells on fibronectin and upregulates $\mathrm{Bcl}-2$ expression. Proc Natl Soc Sci USA 92:61616165. 